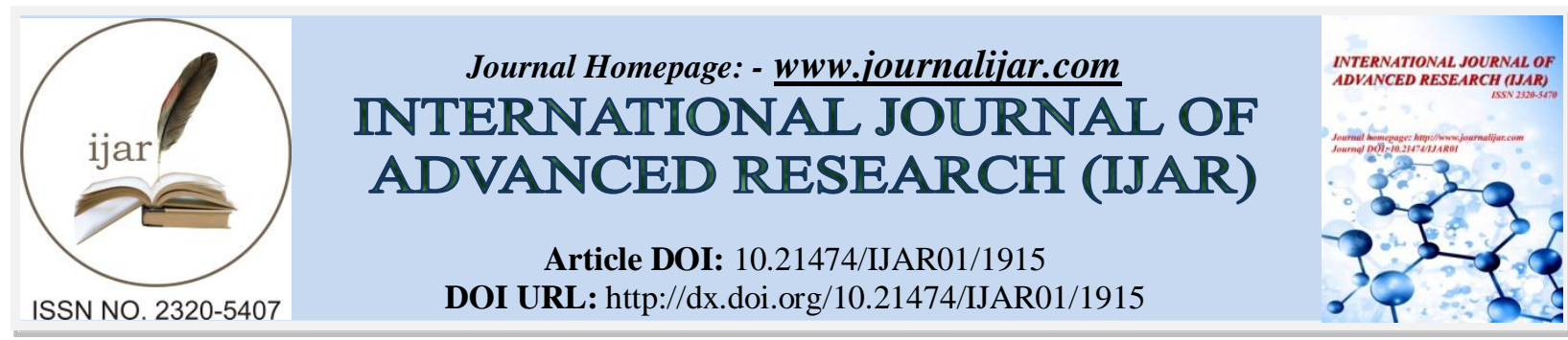

RESEARCH ARTICLE

\title{
CRIMINAL LIABILITY OF DOCTOR IN INDONESIA (FROM A DIGNIFIED JUSTICE PERSPECTIVE)
}

\author{
Teguh Prasetyo.
}

Faculty of Law, Satya Wacana Cristian University (SWCU) Salatiga Jalan Diponegoro 52-60 Salatiga 50711 Jawa Tengah-Indonesia.

\section{Manuscript Info}

Manuscript History

Received: 12 August 2016

Final Accepted: 13 September 2016

Published: October 2016

Key words:-

Criminal Liability, Doctor's Liability,

Pancasila.

\section{Abstract}

In connection with the issue of legal liability of doctor, Indonesian Jurisprudence on medical practice has acknowledged at least three types of doctor's legal liabilities. The three legal liabilities of doctor are: criminal, civil, and ethical or professional liability. To be consistent with the title of this work, this paper will only focus the discussion of doctor's criminal liability according to the Indonesian Jurisprudence or the Dignified Justice theory. The perspective or the theory called Dignified Justice is based on one of its very postulate that a legal system or a jurisdiction is regarded as a dignified legal system if its law and legal system is the manifestation of the spirit of its people (Volksgeist). Pancasila is the Volksgeist. Pancasila consists of two Indonesia words, i.e. panca means five and sila means tenet. Pancasila is the Indonesian five tenets. The first tenet of Pancasila is a believed in the One God Almighty; the second is a just and civilized humanity; the third is a unity of Indonesia; the fourth is a people directed by discretion in the representative deliberations; and the fifth is a social justice for all the Indonesian. Indonesian believes that every laws; common or statutory in the Indonesian legal system must have always contained the spirit of Pancasila.

Copy Right, IJAR, 2016,. All rights reserved.

\section{Introduction:-}

Doctor has confinely been understood in this paper according to the notion as stated in the Indonesia laws and regulation. In an Indonesian statute doctor has restrictedly been understood as general practitioner and dentist. In connection with the issue of legal liability of doctor, Indonesian Jurisprudence on medical practice has acknowledged at least three types of doctor's legal liabilities. The three types of doctor's legal liability has been stipulated in an existing Indonesian Act regulating Medical Practice ${ }^{1}$. The three legal liabilities of doctor are: criminal, civil, and ethical or professional liability ${ }^{2}$. In Indonesia, that ethical liability of doctor has been coined to describe the liability of doctor according to the doctor or medical code of professional conduct.

${ }^{1}$ Law of the Republic of Indonesia Number 29 of 2004 on the Medical Practice, from here onwards will be sbraviated as Law Number 29/2004.

${ }^{2}$ Formulation of the three types of doctor'Ss legal liability in the Pnancasila Legal System are stated in the Article 66 section (3) Law of the Republic of Indonesia Number 29 of 2004 on the Medical Practice. Criminal liability may be imposed upon doctor by way of reporting a suspected criminal act of doctor to the criminal investigator to begin 
Not all of the three types of doctor's legal liability as mentioned above will be discussed in this paper. To be consistent with the title of this work, this paper will only focus the discussion of doctor's criminal liability according to the Indonesian Jurisprudence or the Dignified Justice theory.

The perspective or the theory called Dignified Justice is based on one of its very postulate that a legal system or a jurisdiction is regarded as a dignified legal system if its law and legal system is the manifestation of the spirit of its people (Volksgeist) ${ }^{3}$. The spirit of a people (Volksgeist) manifests itself in the law of the people; particularly in its existing statutes and case laws. Pancasila is the name given to the spirit of the Indonesian people. The Dignified Justice theory suggests that legal institutions, in this case one of it is the institution of criminal liability of doctor in Indonesia must, therefore be studied with reference to the particular Indonesian statutes and case laws that are in force at the moment.

Pancasila is the First Agreement of the people of Indonesia to form a nation and a unitary state or a legal system ${ }^{4}$. Pancasila is therefore has been upheld and believed in the past, now and will continue to stand for the future as the source of all sources of laws in Indonesia. Pancasila consists of two Indonesia words, i.e. panca means five and sila means tenet. Pancasila is the Indonesian five tenets. The first tenet of Pancasila is a believed in the One God Almighty; the second is a just and civilized humanity; the third is a unity of Indonesia; the fourth is a people directed by discretion in the representative deliberations; and the fifth is a social justice for all the Indonesian. Indonesian believes that every laws; common or statutory in the Indonesian legal system must have always contained the spirit of Pancasila. Laws i.e. statutes, rules, principles in regulations and case laws containing the spirit of Pancasila have been found and developed and also published by this writer as the Pancasila Legal System ${ }^{5}$.

Before description and explanation of the doctor's criminal liability according to the Dignified Justice theory, it is necessary here bellow for this writer to begin with a clarification on several important concepts related to the doctor's criminal liability from the perspective of the Dignified Justice theory or the what so called the Indonesian Jurisprudence. The related concept as such are: the nature of doctor, the nature of patient, and the legal obligations of doctor in the Pancasila Legal System.

\section{Doctor, Its Nature in Indonesian Law:-}

Including in the notion of doctor and dentist in the Pancasila Legal system are: (1) doctor (mainly the general practitioner), (2) specialist doctor; (3) dentist; (4) specialist dentist. These four types within the family concept of doctor as such, which included in the title of this paper is regulated in the Republic of Indonesia laws and legislation. Those four types of doctor as such are graduates of medical schools and dentist schools and being acknowledged by the Government of the Republic of Indonesia as dictated by the laws and regulations governing them which are existing in the Pancasila Legal System ${ }^{6}$. It has generally been a common knowledge that all such types of doctor do the medical practice 7 .

with. As for the civil liability of doctor may be obtained by anyone who thinks that he or she has been injured due to the breach of agreement or tort/delict done to him or her by way of suing the doctor in the civil court jurisdiction. For the ethical responsibility or professional liability; everyone who knows that his interesst has been injured as a result of the medical practice conducted by doctor can submit a disciplinary complain to the Indonesian Honorary Medical Disciplinary Assembly Chief, as stated in Article 66 section (1) of the the Law of the Republic of Indonesia Number 29/2004.

${ }^{3}$ Teguh Prasetyo, Keadilan Bermartabat: Perspektif Teori Hukum, Cetakan Pertama, Nusa Media, Bandung, 2015, hlm., 17.

${ }^{4}$ Teguh Orasetyo and Abdul Halim Barkatullah, Filsafat, Theory, \& Ilmu Hukum: Pemikiran Menuju Masyarakat yang Berkeadilan dan Bermartabat, Cetakan Kesatu, RajaGrafindo Persada, Jakarta, 2012, p. 367.

5 Teguh Prasetyo, Sistem Hukum Pancasila: Sistem, Sistem Hukum dan Pembentukan Peraturan PerundangUndangan di Indonesia, Cetakan Pertama, Nusa Media, Bandung, 2016; Cf., Teguh Prasetyo, Hukum dan Sistem Hukum Berdasarkan Pancasila, Cetakan Kesatu, Media Perkasa, Yogyakarta, 2013; Teguh Prasetyo dan Arie Purnomo Sidi, Membangun Hukum Berdasarkan Pancasila, Cetakan Pertama, Nusa Media, Bandung, 2014.

${ }^{6}$ Article 1 number (2) Law Number 29/2004.

7 Definition of medical practice according to Article 1 number (1) Law Number 29/2014. 
By medical practice is to mean a chain of doctor's and dentist's activities toward serving patient with the purposes to undertake the health efforts ${ }^{8}$. In doing the medical practice, either doctor or dentist has legal obligations which has already been listed and regulated in an $\mathrm{Act}^{9}$. Doctor is obligated to provide medical services ${ }^{10}$. The medical services which have been provided and given by doctor and dentist for patient must be in accordance with the standard of operation and procedures and they must be done only to serve the medical needs of patient. By patient is to mean person who come to doctor for consultation on health matter in order to obtain health services done directly or indirectly by doctor or dentist ${ }^{11}$.

Similar to the health sevices, the law has also been using the term Medical Undertaking. By Medical Undertakings is to mean the undertakings done by doctor for patient in terms of diacnostic and therapeutics. Furthermore, it is also contained in the concept of Medical Undertaking an act of invasive treatment. By invasive treatment is to mean one of the types of Medical Undertakings the result of which will directly affecting human body system ${ }^{12}$. In accordance with Article 79 letter (c) Law Number 29/2014, doctor whom undertake to do the Medical Undertakings may only be imposed criminal liability or being punished to the limit of incarceration for no more than one year only or alternatively if managed to pay a fifty milion rupiah fine, doctor would not be put in incarceration or a confinement. That kind of doctor criminal liabilities as such would only be imposed upon doctor in condition that the court of law could extract evidences and that the court could truly proven that doctor in question has intentionally disregarded his or her obligations as stated in Article 51 letter (a) Law Number 29/2014.

\section{Doctor's Liability in the Pancasila Criminal Justice System:-}

In Indonesian Jurisprudence it has been understood that the existence of a criminal liability or punishment must fulfill at least three legal requirements in the Indonesian Criminal Justice System. Firstly it is required that there must be an act done and the act is proven as the act done against the law and punishable. Secondly, that the act done and punishable by the law is an act or an omission that is considered as in contravene with the law. Thirdly, there must be a mens rea in the perpetrator act. For the third legal requirement, it has been thought of in the Indonesian criminal law as an element of wrongful act (schuld). There will be a wrongful act or the act or omission has been done in contravene with the law, the result of the act or omission has been foresight by the agent or that the agent have knowledge, such a prediction or its consequences. Therefore, the agent may have been evaded or discontinue to realise the act, and that the agent is having the capacity to take responsibility or the act is legally blameworthy to the agent in question ${ }^{13}$.

The wrong as mentioned above in the Indonesian criminal law may consist of two types. The first type of wrong is a wrong intentionally done and the second type of wrong is negligence done by the agent. An agent is considered to have done something as intentionally if, an act done or an omission has been taken place as the result of the agent intention and that the agent knows beforehand the consequences of doing the act.

From such a perspective mentioned above, a Medical Undertaking such as doing an operation based on the rights of doctor or authorities of doctor as profesional must in accordance with the recognised rights and obligations to implement doctor's scientific competence and professional skill governing by the law ${ }^{14}$. In the Pancasila Legal System, doctor's rights and authority as regulated in the legislation could be used as "a shield" or a legal justification for medical practice. Doctor's professional rights and authorities may be used as a legal foundation to

\footnotetext{
${ }^{8}$ Article 1 number (11) Law Number 29/2014.

${ }^{9}$ Article 51 Law Number 29/2014.

${ }^{10} \mathrm{By}$ the concept of "medical services" is to mean the concep according to Article 50 letter (b), and Article 51 letter (a). Concept "Medical Services" is a concept mentioned in the Article 50 letter (b), and 51 letter (a) Law Number 29/2014. As for the concep "Health Services" it is also used to mean "Medical Services" in Article 1 number (1) Law Number 29/2014. The nature and types of health services has been regulated in detailed in the another Act, i.e., Law of the Republic of Indonesia Number 36 of 2009 on Health, Article 1 number (11) to number (16); from here onwards is abbreviated as Law Number 36/2009.

${ }^{11}$ Article 1 section (10) Law Number 29/2014.

${ }^{12}$ In the Article 45 of Law oNumber 29/2014 the concept Doctor's Undertaking was used to probably means as the same with Medical Undertakings.

${ }_{13}^{13}$ Teguh Prasetyo, Hukum Pidana, Edisi Revisi, RajaGrafindo Persada, Jakarta, 2013.

${ }^{14}$ Stated in the Article 50 letter (c) Law Number 29/2014.
} 
set aside the character of legal wrong and as an implied exeception to any presumed medical malpractice potentially done by doctor. It is therefore stated in the Article 50 letter (a) of Law Number 29/2014 that doctor has every rights to be protected as long as doctor undertakes their duties in accordance with the doctor code of professional and standard operational procedures.

In the Medical Undertaking the fact is very different compare to what would happen in the ordinary crime. For example a surgeon doing an operation, the operation done by the doctor is an act done as a form of doing his or her best or take his or her best efforts in order to cure the patient, or what the law said to serve the patient's necessary medical need. Apart from it, in every medical act (Medical Undertaking) done by doctor such as an operation there is always possibilities of risks will arise as something unwanted or bad. Therefore in the law it has been a rule that before a surgeon do any operation for patient the doctor have to inform the patient and explain beforehand the character and purpose of the action taken and also stated beforehand any risks that may arise from the process and the risks is a responsibility for the patient to take.

Once the patient has agreed to the action taken by the doctor the patient must expicitly stating his or her consent by signing a letter of acknowledgement or usually termed as informed consent. At present, the above mentioned condition has been stated in Paragraph 2 of Law Number 29/2014 governing the Giving of Consent to Medical Undertaking done by Doctor and Dentist. It has been stated that every Medical Undertaking taken by doctor or dentist for patient must be preceded by an informed consent obtained from the patient ${ }^{15}$.

It has been defined that in principle the person who has the right to give an informed consent is the patient itself. However, if the patient itself is in law in the state of minor or under parental guidances (under curatele), the consent or a refusal to consent to a Medical Undertaking may be given by the closest family member for example wife or husband, father or mother, sons and daughters or brothers and sisters.

In an emergency situation, for the sake of live saving, there is no need to have patient informed consent. However, immediately after the patient is back to his state of consciousness or back in a normal condition to proceeds with normal procedures, patient must be explained and informed consent be made by the patient. In case of patient is a child or an unconscious person the explanation of doctor should be given to the family or anyone who accompany the patient to the doctor's place of practice. If there is no one who accompanied the patient and also no family member but it is a necessary that the Medical Undertaking to be taken for the patient, the doctor explanation should be given to the child or at the first instance immediately after the patient has got back to the state of consciousness ${ }^{16}$.

Informed consent as mentioned above is given after the patient has received a complete explanation from doctor ${ }^{17}$. By complete explanation is: at least it must consist of: a. diagnose and Medical Undertaking procedures; b. purpose of Medical Undertaking to be done by doctor; c. any alternative steps to be taken and all of their potential risks; $d$. risks and complications that may arisen; and e. prognosis to the actions taken by doctor ${ }^{18}$. It has been explained in the law that explanation given by doctor to patient must be given using an ordinary language and that the ordinary language must be easily be understood since the explanation given is the foundation for patient to deliver his or her consent.

The law also states that other important aspect to include in the explanation given by doctor is matter relating to the finances ${ }^{19}$. Informed consent may be given in written or orally ${ }^{20}$. The law also explains, that oral consent is informed consent which was given in the form of patient utters a "yes" sound, or a "nod" and these two oral informed consent have to be taken as expressing a word "agree" or the required informed consent ${ }^{21}$. Written consent is a special condition that must be fulfilled if every Medical Undertaking containing high risks, and the written

\footnotetext{
${ }^{15}$ Article 45 section (1) Law Number 29/2004.

${ }^{16}$ Explanation for Article 45 section (1) Law Number 29/2004.

${ }^{17}$ Article 45 section (2) Law Number 29/2004.

${ }^{18}$ Article 45 section (3) Law Number 29/2004.

${ }^{19}$ Explanation to Article 45 section (3) Law Number 29/2004.

${ }^{20}$ Article 45 section (4) Law Number 29/2004.

${ }^{21}$ Exlpanation to Article 45 section (4) Law Number 29/2004.
} 
consent have to be signed by the person who has the rights or authority to give his or her signature ${ }^{22}$. By "Medical Undertaking with a high risk" is to mean for instance, an operation or any other Invasive Treatment ${ }^{23}$.

Additionally in doing medical practice doctor and dentist has also been obligated to refer patient to other doctor or dentist whom the doctor presumed to have a more expertise or more skill, while the doctor who makes the reference is unable to make the required diagnose and medication ${ }^{24}$. Either it is doctor or dentist is also obliged by law to keep confidentialities they know regarding their patient, even after the patient has already died ${ }^{25}$. Doctor and dentist are also being obligated to give emergency help for humanity sake, except if they believe other doctor in duty are having the ability to do $\mathrm{it}^{26}$. Juridically, doctor and dentist also subject to the necessary requirement to upgrade and catch up with scientific advancement in medicine and dentistry ${ }^{27}$.

Apart from laws and regulations there are also case laws in the Pancasila Legal System governing doctor's legal liabilities particularly governing punishment or sanction imposed on doctor or dentist if they intentionally refused to obey their duties or legal obligations as stipulated in Acts specifically governing them and also another related regulations. In Law Number 29/2004 it has been stated that doctor and dentist whom intentionally refused to obey their juridical obligations which has already been ascertained in the legislation will be imposed with punishments or criminal sanctions $^{28}$. There are at least two relevant types of punishment in Law Number 29/2004 that could be imposed upon doctor or dentist if they fail to comply with the juridical obligations. The two types of sanctions or punishment are incarceration or confinement for not more then one year and a payment of a fine up to maximum fifty million rupiah ${ }^{29}$.

A doctor is considered to have been doing a professional wrong if the doctor is not fulfilling the conditions in deciding diagnose or else doing therapist as a good and average doctor (medicus), does not fulfill the professional standard in the same circumstances and by taking a proportional method to achieve the purpose, he or she negligently (culpa levis) did the act. If all the conditions has been fulfilled by the doctor, for example in a diagnose, or a right therapist, the doctor who have done his duty as a good and average doctor, and could have not been found negligence culpa, either it is light negligence culpa levis or gross negligence culpa lata in him or her. In such a case the doctor could not be judged as criminally negligent. Therefore in this Article 359 and 360 of the Indonesian Criminal Code (ICC) could not be utilized. In other words, conditions as mentioned above are reason used as legal justification to annul the wrongful or blameworthiness of doctor. An example situation in which the justification for annulment is used is when doctor as such is suspected or accused has done things that causing dead or serious injury to patient under his or her care.

It is also contained in the Article 299 of the ICC, that whoever which intentionally medicate a woman or give order for her to be medicated with the information or promise that as a result of the medication her pregnancy is aborted, is threatened with imprisonment to maximum four year or pay a fine maximum forty thousand rupiah. If the act done for profit or used as a occupation or habit, and done by doctor, nurse or pharmacist, the threat of punishment will be added to one third. Article 299 is closely related to the Article 349 of the ICC in which it is stated that if a doctor, nurse or pharmacist are to assist in doing the criminal mentioned in Article 346 or doing or assist in doing one of the crimes explained in the Article 347 and 348 of the ICC the punishment will be added to one third and the license is revoked.

Apart from annulment the wrongfulness or blameworthiness of a criminal act materially as mentioned above, there is also another reason of legal justification to set aside doctor's liability in criminal law. Those justifications are: force majeure or an emergency act, and medical exceptions. Here below this writer will elaborate the three reasons which able to annul the wrongfulness or blameworthiness of any acts done by doctor.

\footnotetext{
${ }^{22}$ Article 45 section (5) Law Number 29/2004.

${ }^{23}$ Explanation to Article 45 section (5) Law Number 29/2004.

${ }^{24}$ Article51 letter (b) Law Number 29/2004.

25 Article51 letter (c) Law Number 29/2004.

${ }^{26}$ Article 51 letter (d) Law Number 29/2004.

27 Article 51 letter (e) Law Number 29/2004.

${ }^{28}$ Article 79 letter (c) Law Number 29/2004.

${ }^{29}$ Ibid.
} 
By force majeure in term of emergency act is a circumstances which subjecting a person must make a choices. The act that the person must undertake is to choose between rules stated in Acts or regulations forbid to do particular acts or to do the restrictions due to the interest to serve in accordance with the obligations to do certain things which is high esteemed and protected by the law. For example, if a psychiatrist is forced not to obey a particular rule mentioned in a legislation to keep the confidentiality of his or her patient since by obeying the rule will cause danger to another life. By medical exception is a legal justification to set aside the wrongfulness of an act existing in the common law or adat law.

In case laws or judge-made laws in the Pancasila Legal System one may find criminal cases were doctor are brought before the court because they were mainly accused as negligently causing dead to person. The case laws as such are described here. The first case law was made before the Independent, and could be seen in Raad van Justice of Medan's decision, made on the 10th of March 1938. In that case, an action was brought before the court against a doctor who was accused by the Public Prosecutor for having done an operation for amputating a patient's thumb. Before doing the operation, the doctor gave order to a nurse who assisting him to provide a $1 / 2 \%$ composite of tutocaine.

We were told that the function of the composite is for the patient to have a local anesthesia. The matter arose since the nurse whom the doctor instructed to do the composite had wrongly taken a 5\% of cocaine instead of the $1 / 2 \%$ composite of tutocaine. Without making sure whether the bottle from which the composite was taken by the nurse was true a bottle containing the requisite composite of the $1 \frac{1}{2} \%$ composite of tutocaine the doctor did several times of the injection on the patient. A half an our later the patient died.

In the decision of the Medan Raad van Justice of the 10th of March 1938 the judges opined that serious mistake done by the nurse who was instructed by the doctor to provide tool and the $1 / 2 \%$ composite of tutocaine coul not be used to decrease the casual relation between the wrong done by the nurse and the doctor and the dead of the patient. The wrong done by the nurse could not be used to justify the innocence of the doctor. The doctor had taken the criminal liability of being punished for negligently causing dead to the patient in the case.

Almost similar to the first case is a case occured in Raad van Justice Medan on the 12nd May 1923. The difference between the first case as mentioned above and this second case is, the mistaken was done by a laboratory staff to provide a composite for an injection took by doctor. The laboratory staff who was instructed to provide 300 milligram of emitine had mistakenly took another substance. Surprisingly in this case the court acquitted the doctor. The Acquital of the doctor was the result of expert testimony (all of the experts are doctors) that the symptoms of the patient's dead was not normally happened and never been encountered by the experts in their carrier and also never been explained in the medical literatures they ever red. The judges whose decided the case could not be convinced that it was 300 milligram emitine that caused the dead of the patient. Since it was unconvincing therefore the judges declared that the accusation made in the prosecution was not legal and unconvincing therefore the judges acquitted the doctor.

\section{Conclusion:-}

Looking from the perspective of the Dignified Justice theory, there are three types of doctor's legal liabilities in the Pancasila Legal System. Those doctor's legal liabilities are: criminal, civil and professional liability. This paper has focused its discussion on the criminal liability of doctor; i.e. if it is proven that an act done by doctor is wrongful or blameworthiness, which is by nature a criminally wrongful act. Viewed from the perspective of the Indonesian Jurisprudence or from the perspective of the Dignified Justice theory, a wrongful act as the basis of criminal liability of doctor can be categorised into an intentionally wrong act and a negligent act as existing in the legislation and also case laws in the Pancasila Legal System. 


\section{Reference:-}

1. Oemar Seno Adji: Buthanasie - Ulasan Hukum dalam Varia Peradilan No. 14 Tahun 1986.

2. Teguh Orasetyo and Abdul Halim Barkatullah, Filsafat, Theory, \& Ilmu Hukum: Pemikiran Menuju Masyarakat yang Berkeadilan dan Bermartabat, Cetakan Kesatu, RajaGrafindo Persada, Jakarta, 2012.

3. Teguh Prasetyo dan Arie Purnomo Sidi, Membangun Hukum Berdasarkan Pancasila, Cetakan Pertama, Nusa Media, Bandung, 2014.

4. Teguh Prasetyo, Hukum Pidana, Edisi Revisi, RajaGrafindo Persada, Jakarta, 2013.

$5 . \quad$ _ Hukum dan Sistem Hukum Berdasarkan Pancasila, Cetakan Kesatu, Media Perkasa, Yogyakarta, 2013.

6. __ Keadilan Bermartabat: Perspektif Teori Hukum, Cetakan Pertama, Nusa Media, Bandung, 2015.

$7 . \longrightarrow$ Sistem Hukum Pancasila: Sistem, Sistem Hukum dan Pembentukan Peraturan PerundangUndangan di Indonesia, Cetakan Pertama, Nusa Media, Bandung, 2016.

8. Undang-Undang Republik Indonesia Nomor 29 Tahun 2004 tentang Praktik Kedokteran.

9. Undang-Undang Republik Indonesia Nomor 36 Tahun 2009 tentang Kesehatan.

10. Peraturan Menteri Kesehatan Republik Indonesia Nomor: 585/MEN.KES/PER/IX/1989. 